\title{
Ekspresi Emosi Marah
}

\author{
Safiruddin Al Baqi ${ }^{1}$ \\ Program Studi Magister Psikologi \\ Fakultas Psikologi Universitas Gadjah Mada
}

\section{Pengantar}

Manusia merupakan makhluk sosial yang tidak bisa hidup sendiri, dan setiap individu tidak lepas dari hubungan sosial dengan orang lain. Semua interaksi sosial yang dilakukan seorang individu memunculkan emosi dalam diri setiap individu. Dari emosi tersebut kemudian individu dapat menentukan sikap dan pikiran sehingga mampu bertindak sesuai dengan dirinya (Lewis \& Jones, 2000). Seperti putus pacar pada remaja memunculkan emosi sedih sehingga berperilaku menarik diri atau murung dan bahkan kaki yang tidak sengaka terinjak juga akan memunculkan emosi marah.

Linschoten (Sundari, 2005) menjelaskan bahwa perasaan manusia menurut modalitasnya terbagi menjadi tiga, yakni suasana hati, perasaan itu sendiri, dan emosi. Emosi merupakan bagian dari perasaan dalam arti luas. Emosi tampak karena rasa yang bergejolak sehingga yang bersangkutan mengalami perubahan dalam situasi tertentu mengenai perasaan, namun seluruh pribadi menanggapi situasi tersebut. Pada akhirnya, individu dapat menyesuaikan diri dengan lingkungannya dan menentukan respons yang sesuai terkait situasi yang dihadapi.

Emosi berkembang sejak anak lahir, emosi ditimbulkan oleh adanya rangsang. Pengalaman-pengalaman sehari-hari yang dialami individu dalam menghadapi suatu

\footnotetext{
${ }^{1}$ Koresponsdensi mengenai isi artikel ini dapat melalui: safiruddinalbaqi@gmail.com
}

rangsang akan mempertajam kepekaan emosi serta ketepatan dalam mengekspresikan emosinya. Pada masa anak-anak ekspresi emosi sulit dibedakan. Misalnya ekspresi menangis pada anak atau bayi dapat berarti marah, lapar, takut dan sebagainya. Makin besar atau makin dewasa makin banyak anak belajar mengekspresikan emosi ke dalam masyarakatnya. Selain itu anak makin dapat membedakan rangsang atau stimulus dari lingkungan. Emosi nampak dari luar sebagai perilaku yang sesuai dengan caracara yang dipelajari dari masyarakatnya. Pengalaman sangat memengaruhi perkembangan dan kemasakan emosi. Orang yang mempunyai banyak pengalaman positif tentu akan memiliki perkembangan dan kemasakan emosi yang berbeda dengan anak yang sedikit mengalami pengalaman positif (Sundari, 2005).

Goleman menjelaskan bahwa pada prinsipnya emosi dasar manusia meliputi takut, marah, sedih dan senang. Sutanto (2012) menambahkan malu, rasa bersalah, dan cemas sebagai emosi dasar manusia. Emosi tersebut penting karena sangat berpengaruh tidak hanya pada perilaku saat ini namun juga perilaku dimasa mendatang, terutama emosi negatif. Sedangkan marah sendiri merupakan reaksi terhadap sesuatu hambatan yang menyebabkan gagalnya suatu usaha atau perbuatan. Marah yang timbul seringkali diiringi oleh berbagai ekspresi perilaku.

Banyak individu mulai dari dari anak, remaja bahkan orang dewasa sulit meng- 
ungkapkan secara lisan tentang marah yang dirasakan. Mereka mungkin sadar setiap kali mereka mengekspresikan marah dengan perilaku yang kurang bisa diterima secara sosial, namun mereka tidak mampu mencegahnya terjadi. Hal ini disebut sebagai emotionally illiterate atau kebutaan emosi yang diiringi dengan kurangnya kemampuan untuk memahami perasaan dan kurang mampu memahami bagaimana mengekspresikan marah yang dapat diterima secara norma sosial (Duffy, 2012). Sehingga tidak jarang banyak kasus tawuran remaja hingga pembuhuhan sadis yang akarnya adalah kemarahan yang diekspresikan dengan kurang tepat.

Dalam tulisannya, Duffy (2012) mengungkapkan bahwa marah adalah sesuatu yang sangat normal dan merupakan perasaan yang sehat. Namun sangatlah penting untuk membedakan antara marah, agresi dan kekerasan yang sering kali disamakan. Marah merupakan potensi perilaku, yakni emosi yang dirasakan dalam diri seseorang. Sedangkan agresi atau kekerasan merupakan perilaku yang muncul akibat emosi tertentu, khususnya marah. Emosi marah tidak harus berujung pada perilaku agresi, marah yang dikelola dengan baik akan memunculkan perilaku yang dapat diterima norma sosial seperti perilaku asertif, namun jika marah tidak mampu dikelola dengan baik, maka marah dapat berdampak pada munculnya perila$\mathrm{ku}$ agresi atau kekerasan yang tidak diterima norma sosial.

Penelitian Cautin dkk. (2001) terhadap 92 remaja menunjukkan bahwa marah mempunyai peran yang sangat penting bagi timbulnya depresi dan menjadi salah satu faktor yang menyumbangkan risiko bunuh diri bagi remaja. Mereka menggolongkan ekspresi marah yaitu diinternalisasi atau dipendam sendiri dan dieksternalisasi atau diekspresikan pada ling- kungannya. Hasilnya menunjukkan bahwa remaja yang menginternalisasi marahnya mempunyai kecenderungan terhadap depresi, dan terlebih lagi mengarah pada kemungkinan bunuh diri. Sedangkan remaja yang mengekspresikan marahnya secara eksternal maka mempunyai kecenderungan terhadap penyalahgunaan obatobatan dan alkohol.

Dari berbagai perbedaan ekspresi marah yang dimiliki individu, penulis ingin menganalisis apa yang menyebabkan perbedaan ekspresi ini. Untuk mempermudah hal ini, maka akan dibandingkan beberapa ekspresi marah yang ada pada beberapa budaya, sebelum dianalisis lebih lanjut.

\section{Senyuman: Ekspresi Marah Suku Jawa, Indonesia}

Masyarakat suku Jawa memiliki beberapa prinsip yang selalu dipegang dalam setiap melakukan hubungan interpersonal, diantaranya prinsip rukun atau harmonis yang mengutamakan hubungan baik antar manusia, dengan mencegah berkelahi terbuka, penuh penghormatan terhadap sesama, gotong royong, tenggang rasa (tepa selira), dan ramah-tamah penuh kelembutan (Suseno, dalam Kurniawan \& Hasanat 2010).

Masyarakat Jawa juga dikenal memiliki aturan yang baku dalam penggunaan bahasa, tutur kata dan etika. Misalnya, ketika orang yang lebih muda berbicara dengan orang yang jauh lebih tua, maka orang yang lebih muda harus menggunakan bahasa kromo inggil sebagai penghormatan terhadap orang yang lebih tua. Lebih lanjut lagi, dalam budaya Jawa orang harus berbicara perlahan-lahan dan halus, sedapat mungkin "menyembunyikan" perasaan asli sebagai pengejawantahan dari prinsip isin dan sungkan. Kedua prinsip keselarasan itu sebagai pedoman bagi masyarakat Jawa dalam pergaulan 
sehari-hari. Prinsip tersebut menuntut agar semua lapisan masyarakat Jawa, pada semua golongan usia, remaja dan dewasa senantiasa mengontrol dorongan-dorongan diri sendiri. Semakin individu mampu mengontrol dorongan dorongan emosinya dan semakin menguasai tata krama pergaulan, maka semakin ia dianggap dewasa dan diakui sebagai anggota masyarakat Jawa (Suseno, dalam Kurniawan \& Hasanat 2010).

Dari penjeasan diatas maka diketahui bahwa masyarakat suku Jawa juga memiliki aturan-aturan normatif perilaku sosial dan psikologis. Aturan normatif tersebut mengatur masyarakatnya dalam melakukan interaksi sosial dengan sesamanya, seperti sopan santun, etika, dan tata cara yang pantas dalam pergaulan sehari-hari. Hal ini dilakukan untuk menjaga keharmonisan dan keselarasan hidup. Aturan-aturan ini tertanam secara turun temurun dan berusaha dilakukan semenjak individu berusia anak-anak, remaja, dewasa hingga tua (Elip, dalam Kurniawan \& Hasanat 2010).

Terdapat keyakinan pula di masyarakat Jawa bahwa memperlihatkan perasaan-perasaan secara spontan dianggap kurang pantas, seperti gembira, sedih, kecewa, marah, putus asa, harapanharapan, atau rasa belas kasihan yang akan disembunyikan untuk tidak diperlihatkan pada banyak orang. Sehingga kebanyakan masyarakat Jawa akan memperlihatkan senyuman sebagai ekspresi marah, demi menjunjung prinsip-prinsip diatas.

Bunuh Diri: Ekspresi Marah Masyarakat Sri Lanka

Sejak pertengahan abad-20, perilaku bunuh diri meningkat tajam di Sri Lanka, bahkan menempati peringkat atas dari tingkat bunuh diri dunia. Siapa yang melakukan bunuh diri menjadi sangat beragam mulai dari lintas jender, kelas sosial bahkan usia. Sebuah penelitian yang dilakukan oleh Widger (2012) ingin mencari tahu "siapa" saja yang melakukan bunuh diri diharapkan akan mengetahui juga "mengapa" mereka melakukan tindakan ini. Setelah melakukan penelitian berbasis etnografi, peneliti menyimpulkan beberapa hal terkait penyebab bunuh diri yang banyak dilakukan masyarakat Sri Lanka.

Penderitaan merupakan emosi yang sering dilaporkan oleh penduduk Sri Lanka, penderitaan ini merujuk pada emosi sedih dan perasaan tak berdaya. Sesungguhnya agama yang dianut masyarakat telah memberikan solusi pada penderitaan mereka, yakni praktik ibadah agama Budha, Katolik Roma dan Islam. Namun tekanan dari berbagai masalah utamanya ekonomi disinyalir menjadi faktor pendukung terjadinya bunuh diri. Mereka juga tidak memiliki strategi koping yang baik, sehingga permasalahanpermasalahn yang dihadapi akan berujung pada bunuh diri, seperti masalah kekerasan dalam rumah tangga (KDRT) dan perceraian. Selain penderitaan, frustrasi juga menjadi penyumbang besar bagi bunuh diri. Kebanyakan, perasaan ini datang dari kehidupan sosial seperti tekanan pekerjaan dan hubungan dengan orang lain.

Kemarahan, utamanya yang intens dan mendadak dapat menjadi pemicu bunuh diri bagi penduduk Sri Lanka (anger suicide). Seperti yang dilaporkan bahwa banyak orang melakukan bunuh diri setelah mereka dihadapkan pada situasi yang memicu marah. Seperti marah karena ditolak pasangan, marah karena perilaku suami, marah karena beradu mulut dengan mertua. 
Kenakalan remaja vs Bunuh Diri: Ekspresi Marah Remaja Amerika Serikat (USA)

Cautin dan kawan-kawan pada tahun 2001, melakukan sebuah penelitian yang bertujuan untuk mengetahui dampak dari menginternalisasi dan eksternalisasi marah pada remaja. Dengan asumsi bahwa tingkat keparahan depresi berhubungan positif dengan tingkat permusuhan dan kemarahan yang dimiliki seseorang, dan agresi merupakan manifestasi yang paling umum dari marah, begitu pula dengan bunuh diri. Eksternalisasi dari marah sangat mungkin terkait dengan beberapa psikopatologi seperti penggunaan obat terlarang, dan alkohol. Level eksternalisasi marah yang lebih besar berhubungan dengan tingkat bunuh diri yang lebih rendah.

Hasil-hasil penelitian menunjukkan bahwa marah mempunyai peran yang sangat penting bagi timbulnya depresi dan menjadi salah satu faktor yang menyumbangkan risiko bunuh diri bagi remaja. Mereka menggolongkan ekspresi marah yaitu diinternalisasi atau dipendam sendiri dan dieksternalisasi atau diekspresikan pada lingkungannya. Hasilnya menunjukkan bahwa remaja yang menginternalisasi marahnya mempunyai kecenderungan terhadap depresi, dan terlebih lagi mengarah pada kemungkinan bunuh diri. Sedangkan remaja yang mengekspresikan marahnya secara eksternal maka mempunyai kecenderungan terhadap penyalahgunaan obat dan alkohol.

Penelitian sebelumnya yang dilakukan oleh Seigman dan Snow (1996) pada remaja akhir di Maryland mengungkapkan bahwa umumnya terdapat tiga ekspresi marah yang mungkin muncul. Pertama adalah anger-out, yakni kemarahan yang muncul secara spontan dan cepat dan biasanya ditandai dengan teriakan, makian yang ditujukan kepada objek kemarahan, yang kedua adalah anger-in, yakni kemarahan yang cenderung dirasakan sendiri tanpa mengungkapkannya dan biasanya disalurkan dengan imajinasi, yang ketiga adalah mood incongruent speech, yakni mengungkapkan kemarahan dengan suara pelan dan lembut. Pengekspresian ini terkait dengan level kemarahan yang dirasakan individu yakni mood incongruen speech muncul saat individu merasakan level kemarahan yang rendah, anger-in saat kemarahan level sedang, dan anger -out saat kemarahan yang dirasakan mencapai level tinggi.

Perilaku Agresi: Ekspresi Marah Narapidana di India dan Australia

Pengaruh budaya dalam mengalami dan mengekspresikan emosi telah diketahui secara luas. Dimana budaya mengajarkan pada individu untuk mengenali emosi apa yang tepat, bagaimana mengkomunikasikan dan bagaimana mengontrolnya dalam berbagai situasi. Sebuah penelitian terkait perkembangan emosi yang ditanamkan dalam keluarga yang berasal dari berbagai budaya dilakukan oleh Raval dkk. (2011). Penelitian tersebut dilakukan pada para narapidana yang terlibat kasus agresi, dari penganiayaan hingga pembunuhan. Hasilnya menunjukkan bahwa semua subjek mengatakan bahwa kekerasan atau kesalahan yang mereka lakukan berawal dari emosi yang tidak terkendali khususnya marah kepada korbannya. Sehingga yang terjadi adalah memukul, melempar dengan batu dll., saat mereka merasa dirugikan korbannya meskipun dikarenakan hal kecil. Pengaruh keluarga juga sangat kuat, 11 dari 14 subjek mengatakan bahwa ayah mereka adalah seorang yang mudah sekali marah. Penyebab kemarahan yang umum adalah caci-makian yang disasarkan kepada seseorang dan ketika seseorang tidak cepat 
mengerti akan permintaan penjelasan yang diberikan. Hal-hal yang menyertai marah diantaranya adalah respons fisik seperti mata merah, jantung berdebar dan lain-lain, namun tidak berhenti disini beberapa subjek mengatakan bahwa kemarahannya sering berujung dengan memukul atau memaki objek marah. Espresi marah yang ditunjukkan para subjek juga bergantung pada situasi ataupun objek marah yang sedang dihadapi, umumnya mereka tidak langsung melakukan agresi, namun perubahan menjadi agresi sangat cepat melebihi orang yang bukan pemarah. Meskipun mereka adalah individu pemarah, namun 10 dari 14 anak mengatakan bahwa marah bukanlah hal yang baik dan tidak sesuai jika diekspresikan dengan cara yang telah mereka lakukan selama ini.

Penelitian ini menunjukkan bagaimana pandangan marah dari para remaja India yang melakukan tindakan kriminal khususnya kekerasan yang didasarkan pada emosi marah mereka. Dengan mengetahui bagaimana mereka memandang, mengalami dan mengekspresikan kemarahan, diharapkan akan membantu menemukan solusi untuk memberikan perlakuan kepada remaja ini.

Penelitian serupa dilakukan oleh Day dkk. (2006) yang dilakukan dengan subjek narapidana Australia yang terlibat kasus kekerasan. penelitian ini nenunjukkan bahwa mereka menganggap atau menyemakan konteks marah dengan kekerasan, ketika mereka menceritakan kemarahan pasti terdapat unsur kekerasan didalamnya. Mereka juga menganggap bahwa marah yang diekspresikan dengan kekerasan bukanlah seseuatu yang nyaman, dimana mereka mengalami emotional disstress setelah itu. Para narapidana tidak mampu membedakan sejumlah emosi dengan baik, dimana sering campur aduk antara marah, sedih, takut dan cinta. Penelitian ini juga mengungkapkan sebabsebab kemarahan pada narapidana asli Australia, diantaranya; kehilangan, masalah keluarga, alkohol dan obat-obatan lain dan diskriminasi. Sehingga dapat disimpulkan bahwa ketidakmampuan mendefinisi marah dengan baik bahkan tidak mampu membedakan sejumlah emosi yang mereka rasakan sehingga masalahmasalah kecil bisa berujung pada kemarahan bahkan tindak kekerasan.

Pengaruh Budaya dalam Pengelolaan dan Pengekspresian Marah

Dalam masyarakat luas, banyak berkembang pemikiran yang salah mengenai marah, salah satunya adalah bahwa cara seseorang mengekspresikan marah merupakan hasil dari keturunan (hereditas) yang diturunkan oleh orang tua dan hal itu tidak bisa dirubah. Salah satu pendekatan yang dapat menjelaskan perbedaan pengelolaan dan ekspresi marah adalah pendekatan cognitive-behavior. Pendekatan cognitive-behavior mengedepankan bahwa proses berpikir dan emosi berpengaruh pada perilaku yang muncul (apakah sesuai harapan sosial atau tidak). Ketika ada suatu peristiwa maka pikiran dan emosi akan merespons dan menentukan perilaku apa yang akan dimunculkan (Beck dalam Duffy, 2012). Pendekatan ini juga meyakini bahwa bahwa ekspresi marah merupakan perilaku yang dapat dipelajari, sehingga ekspresi marah yang baik juga bisa dipelajari (Reilly \& Shopshire, 2002).

Kebanyakan perilaku seseorang merupakan hasil dari pembelajaran, yakni dengan memperhatikan orang lain, terutama orang-orang yang berpengaruh. Orang-orang tersebut adalah orang tua, anggota keluarga yang lain dan teman. Jika seorang anak memperhatikan orang 
tuanya mengekspresikan marah dengan perilaku agresif, seperti mencaci-maki dan tindak kekerasan, sangat mungkin bahwa anak tersebut akan melakukan hal yang sama ketika mengekspresikan marah karena ia telah belajar perilaku yang demikian. Untungnya, perilaku ini dapat diubah dengan cara mempelajari perilaku baru dalam mengekspresikan marah, sehingga tidak perlu lagi mengekspresikan marah dengan cara-cara agresif dan juga keras (Reilly \& Shopshire, 2002).

Perspektif lain yang dapat menjelaskan perbedaan kontrol marah dan bagaimana lingkungan termasuk budaya memengaruhi seorang individu adalah self-control theory. Teori ini memandang bahwa sebelum menjadi respons perilaku, stimulus yang berasal dari luar, akan terlebih dahulu diproses dalam diri seseorang melalui Cognitive-affective Processing System (CAPS). CAPS memiliki tiga ciri khas, yaitu: (1) Aspek kognitif dan emosi saling berkaitan satu sama lain. Pemikiran mengenai tujuan akan memicu pemikiran mengenai keterampilan, dan akhirnya memicu pemikiran self-efficacy. Pada akhirnya memengaruhi self-evaluations dan emosi, (2) Aspek situasi yang berbeda mengaktivasi bagian tertentu dari keseluruhan sistem kepribadian, dan (3) Apabila situasi yang berbeda mengaktivasi bagian tertentu dari keseluruhan sistem kepribadian, maka perilaku manusia harus berbeda dari satu situasi ke situasi lainnya.

Dengan demikian ketika seseorang menerima stimulus yang dapat memicu marah, contohnya seperti kaki yang tidak sengaja terinjak orang lain, maka kemarahan yang muncul akan sangat dipengaruhi CAPS, dalam hal ini dipengaruhi situasi, siapa objek marah yang dihadapi, individu itu sendiri dan juga budaya yang ia bawa. Menurut teori ini, kemungkinan kemungkinan yang dapat terjadi dalam keadaan ni adalah: (1) Jika yang terinjak berada dalam situasi formal seperti dalam rapat atau kelas, mungkin hanya akan mengatakan "maaf, kaki saya terinjak oleh Saudara". Dengan nada sopan tanpa disertai nada marah/tinggi. (2) Jika kejadian ini berada dalam situasi penuh sesak dan ditempat umum seperti saat nonton konser atau di terminal, maka bisa jadi yang terinjak akan marah hingga melakukan agresi verbal maupun nonverbal, namun munculnya kemarahan sangat tergantung dari anger management dan siapa yang menjadi objek marah, kepribadian individu, dan nilai-nilai yang dipegang.

Banyak pandangan barat menganggap bahwa perilaku asertif merupakan perilaku yang paling tepat dalam mengekspresikan marah. Pengekspresian marah dapat digolongkan menjadi tiga, yakni asertif, agresif dan pasif. Agresi merupakan perilaku yang ditujukan untuk merugikan atau melukai orang lain atau dengan merusak barang. Yang termasuk perilaku agresi meliputi perkataan kasar, mengancam, dan perilaku kekerasan/menyerang. Sering kali, ketika orang lain mengganggu ketenangan, reaksi pertama adalah melawannya balik atau membalasnya. Kesan utama yang dapat diambil dari agresi adalah "perasaan, pikiran dan keyakinan$\mathrm{ku}$ itu penting dan perasaanmu, pikiran$\mathrm{mu}$, dan keyakinanmu itu tidak penting.

Cara yang digunakan selain agresi adalah perilaku pasif atau berlaku tidak tegas. Berlaku pasif atau tidak tegas merupakan cara yang tidak diharapkan atau tidak baik karena membiarkan hak diri diserang. Mungkin seseorang merasa benci (marah) ketika diganggu orang lain, dan juga akan merasa marah pada diri sendiri katika tidak mempertahankan diri. Dan bisa saja ia akan merasa lebih marah ketika bertemu lagi dengan orang yang 
menjadi objek marah. Kesan utama yang dapat diambil dari perilaku pasif adalah "perasaan, pikiran dan keyakinanmu itu penting, tapi perasaan, pikiran dan keyakinanku itu tidak penting. Berperilaku pasif atau tidak tegas mungkin merupakan satu cara yang membantu untuk menghindari akibat negatif yang disebabkan agresi, tapi perilaku tidak tegas akan mengarahkan pada dampak negatif pada pribadi sendiri, seperti harga diri yang menjadi redah, dan membuat kebutuhan kepuasan seseorang terhalangi.

Dari sudut pandang pengaturan marah, cara terbaik untuk menghadapi orang yang meyerang hak orang lain adalah dengan berlaku tegas. Yang termasuk berlaku tegas adalah mempertahankan hak dengan cara yang sopan terhadap orang lain. Kesan utama yang dapat diambil dari perilaku tegas adalah, "perasaan, pikiran, dan keyakinanku itu penting, dan perasaan, pikiran dan keyakinanmu juga sama pentingnya."

Dengan berlaku tegas, seseorang dapat mengekspresikan perasaan, pikiran dan keyakinan seseorang pada orang lain yang mengganggu haknya tanpa mengalami konsekuensi negatif yang diakibatkan perilaku agresi dan juga tanpa mengorbankan perasaan diri sendiri, yang disebabkan oleh perilaku pasif atau tidak tegas. Sebagai kesimpulan, yang termasuk perilaku agresi adalah mengekspresikan perasaan, pikiran, dan ide dengan cara yang membahayakan atau tidak sopan. Yang termasuk perilaku pasif atau tidak tegas adalah tidak mengekspresikan perasaan, pikiran dan ide atau mengekspresikannya dengan cara menyalahkan diri sehingga orang lain tidak mempedulikanmu. Yang termasuk perilaku tegas adalah mempertahankan hak diri dan mengekspresikan perasaan, pikiran, dan ide secara langsung/segera, jujur, dan dengan cara yang sesuai yang dapat mengyerang hak orang lain dan cara yang menunjukkan ketidaksopanan.

Namun demikian, tidak mudah mengajarkan ekspresi marah yang tepat bagi seseorang jika hal ini tidak dilakukan sejak dini, seperti penelitian Al Baqi (2013) yang dilakukan untuk mengajarkan ekspresi dan pengelolaan marah pada remaja SMA. Dengan mengadopsi teknik dari barat, yakni cognitive behavior therapy (CBT), ternyata hasil penelitian ini menunjukkan bahwa tidak ada perubahan yang signifikan pada pengelolaan marah para partisipan penelitian.

\section{Penutup}

Selain budaya, terdapat beberapa faktor lain yang memengaruhi emosi marah seseorang, baik dalam perasaan ataupun pengekspresiannya. Seperti pola asuh, perbedaan jender dan lain-lain. Quigley dkk. (2006) dalam penelitiannya menyebutkan bahwa perilaku yang dipelajari oleh remaja dalam keluarga sangat berpengaruh tidak hanya dalam perilaku secara umum, namun juga dalam pengekspresian emosi marah yang merujuk pada kekerasan. hal ini terkalit dengan pola asuh (parental monitoring) dan juga kelekatan (attachment) dengan anggota keluarga khususnya orang tua. Quigley dkk. (2006) menambahkan bahwa teman sebaya juga berpengaruh terhapat pengeloaan dan pengekspresian marah. Teman sebaya merupakan pengaruh yang sangat kuat bagi remaja hampir dalam semua aspek termasuk penyalahgunaan obat terlarang, alkohol, dan juga perilaku lain, baik buruk maupun yang baik. Hal ini disebabkan karena remaja cenderung membuat perkumpulan dan memunculkan suatu norma kelompok yang secara tidak langsung harus diikuti oleh setiap anggotanya, jika 
tidak diikuti maka akan berujung pada pengucilan.

Ramirez dkk. (2001) dalam penelitian lintas budayanya menyebutkan bahwa marah dan agresi dipengaruhi oleh budaya atau masyarakat dimana individu tinggal. Ada beberapa masyarakat yang menganggap bahwa agresi verbal berupa makian dan bentakan adalah hal yang umum atau biasa dilakukan, sedangkan masyarakat lain menganggap bahwa hal tersebut dapat melukai seseorang (seperti perbedaan dalam budaya Belanda, Spanyol dan Jepang dalam penelitian Ramirez dkk., (2001).

Berbeda dengan jenis kelamin yang mutlak ada sejak lahir yakni terlahir sebagai laik-laki dan perembuan, jender lebih fleksibel tergantung peran yang diambil seseorang dalam berinteraksi dalam masyarakat, yakni siapapun bisa menjadi maskulin atau feminin. Kinney dkk. (2001) menyebutkan bahwa jenis kelamin tidak berpengaruh terhadap kemarahan dan agresi verbal, namun jender berpengaruh terhadap keduanya. Seseorang dengan jender maskulin akan cenderung memiliki kemarahan dan agresifitas verbal yang tinggi, begitu pula sebaliknya pada individu feminim akan cenderung memiliki kemarahan dan agresifitas verbal yang rendah. Sedangkan Fischer dkk. (2011) menyebutkan adanya perbedaan dimana laki-laki lebih aktif atau ekspresif.

\section{Daftar Pustaka}

Al Baqi, S. (2013). Pengaruh CognitiveBehavior Group Therapy Terhadap Peningkatan Anger Management. Malang: Universitas Negeri Malang

Cautin, R. L., Overholser, J. C., \& Goetz, P. (2001). Assesment of Mode of Anger Expression In Adolescent Psychiatric
Inpatients. Proquest Sociology, 36(141), 163-170.

Day, A., Davey, L., Wanganeen, R., Howells, K., DeSantolo, J., \& Nakata, M. (2006) The meaning of anger for Australian Indigenous offenders: the significance of context, International Journal of Offender Therapy and Comparative Criminology, 50(5), 520-539, The Association, London, England [C1.1]ERA journal ID: 6319 - Scopus

EID: 2-s2.0-33748131782

Duffy, J. (2012). Managing Anger and Aggression: Practical Guidance for Schools. South Eastern Education and Library Board: Psychology/ Behavior Support Section.

Fischer, A. H., \& Evers, C. (2011). The Social Costs and Benefits of Anger as a Function of Gender and Relationship Context. Sex Roles, 65, 23-34

Kinney, T. A., Smith, B. A., \& Donzella, B. (2001). The Influence of Sex, Gender, Self-Discrepancies, adn SelfAwareness on Anger an Verbal Aggressiveness Among U. S. College Students. The Journal of Social Psychology, 141(2), 245-275.

Kurniawan, A. P., \& Hasanat, N. U. (2010). Ekspresi Emosi pada Tiga Tingkatan Perkembangan pada Suku Jawa Di Yogyakarta: Kajian Psikologi Emosi dan Kultur pada Masyarakat Jawa. Jurnal Psikologi Indonesia, VII(1), 50-64.

Lewis, M., \& Haviland-Jones, J. M. (2000). Handbook of Emotion 2nd Edition. New York: The Guilford Press.

Quigley, D. D., Jaycox, L. H., McCaffrey, D. F., \& Marshall, G. N. (2006). Peer and Family Influences on Adolescent Anger Expression and the Acceptance of Cross-Gender Aggression. Violevce and Victim, 21, 597-610.

Ramirez, J. M., Fujihara, T., \& Van Goozen, S. (2001). Cultural and Gender Differences in Anger and Aggression: 
A Comparason Between Japanase, Dutch, and Spanish Students. The Journal of Social Psychology, 141(1), 119121.

Raval, V. V., Raval, P. H., \& Becker, S. P. (2012). He Cursed, and I Got Angry: "Beliefs About Anger Among Adolescent Male Offenders in India. Journal of Child and Family Study, 21, 320-330

Rilley, P. M., \& Shopshire, M. S. (2002). Anger Management for Substance Abuse and Mental Health Clients: A Cognitive Behavior Theraphy Manual. Washington: U.S. Department of Health and Human Service.
Sigman, A. W., \& Snow, S. C. (1996). The Outward Expression of Anger, the Inward Experience of Anger and CVR: The Role of Vocal Expression. Journal of Behavioral Medicine, 20(I), 29-45.

Sundari, S. (2005). Kesehatan Mental Dalam Kehidupan. Jakarta: Rineka Citra

Sutanto, L. (2012). Organisasi-Self Berbasis Emosi. Makalah disajikan pada Mata Kuliah Psikoterapi Semester Genap Jurusan Psikologi FPPsi UM, Malang.

Widger, T. (2012). Suffering, Frustration, and Anger: Class, Gender and History in Sri Lankan Suicide Stories. Cult Med Psychiatry, 36, 225-244. 